\title{
A STUDY ON THE FACTOR INFLUENCING BIRTH REGISTRATION IN KAMRUP DISTRICT OF ASSAM
}

Papiya Das ${ }^{1}$

\section{HOW TO CITE THIS ARTICLE:}

Papiya Das. "A Study on the Factor Influencing Birth Registration in Kamrup District of Assam". Journal of Evolution of Medical and Dental Sciences 2015; Vol. 4, Issue 86, October 26; Page: 14949-14955,

DOI: $10.14260 /$ jemds/2015/2123

ABSTRACT: BACKGROUND: Births and Deaths are the vital events and knowledge about these events is essential for the demography, health and other civil rights. This system of birth and death registration is called Civil Registration System and for proper implementation of vital registration India has enacted The Registration of Births and Deaths Act, 1969. Under this act any vital event i.e. birth, death and still birth are to be registered within 21 days of the event. OBJECTIVE: This study was done with the objective to find the level of registration of birth and to study the influence of socio demographical factors on the registration of birth. MATERIAL AND METHODS: A community based cross sectional study was done where data were recorded in pretested predesigned interview schedule and data analysis was done manually. RESULTS: It was seen that only $61.63 \%$ of births were registered and in urban areas $71.05 \%$ of birth were registered whereas only $54.17 \%$ in rural areas. In case of religion it was noticed that $65.67 \%$ of Hindu births were registered whereas in case of Muslim births it was $47.37 \%$. An association had been found between the level of education and status of registration. But no association had been noted between registration and socioeconomic status or place of delivery. Those who were registered, most (52.83\%) of them got their certificate after 30 days of registration.

KEYWORDS: Birth registration, Factor, Community.

INTRODUCTION: India, being a signatory to the United Nation Convention on Rights of the Child, 1989 must have registered all child by now. The right to be registered immediately after birth and to acquire a name and a nationality is recognized under article 7 of the Convention on the Rights of the Child. But in reality we are the country with highest number of unregistered birth registration provides the first identity to the child and it is also the document to prove the child's parentage. It is the right of every child to be registered and provided a birth certificate.

Though birth registration is an important document but its value is overlooked. The UNICEF report shows the percentage of annual births not registered by region in 2000. In sub-Saharan Africa, over 70 per cent of births went unregistered, as were 63 per cent in South Asia. South Asia tops the league in terms of sheer numbers of unregistered children, with approximately 22.5 million, or over 40 per cent of the world's unregistered births in 2000, compared to a total of around 17 million in subSaharan Africa. In the Middle East and North Africa, nearly one-third of the children born in 2000 (or some 3 million) lacked legal recognition of their identity, while in the East Asia and Pacific region 22 per cent of births in 2000 - some seven million children-were unregistered.(1) Birth and death registration system is known as Civil Registration System (CRS).

Under this system births, deaths and still births are required to be registered to the concerned Registrar with 21 days of its occurrence. For proper implementation of this system, Registration of Births and Deaths Act, 1969 (RBD Act, 1969) was enacted but still we are lagging far behind. The NFHS III (2006) survey found that in India, children with educated parents and from the higher socio economic were more likely to have their births registered. 
The births of less than one fourth of children belonging to households in the lowest wealth strata had been registered and only 1 in 10 had a birth certificate.(2)

The present scenario in Assam was 74.58\% of births were registered in 2008 that of deaths registration was $31.82 \%$, this data was based on the monthly returns received from the districts (Office of the Director of Health Services, Health A, Hengarabari, Assam). According to NFHS III (2006) births registered in children less than 5 years of age in Assam was 43\%. The figure for Kamrup district for births and deaths registration was 34.58\% and 17.3\% respectively in year 2008 (Office of the Director of Health Services, Health A, Hengarabari, Assam). These data show that we still have to go a long way to achieve our goal of $100 \%$ registration of births and deaths.

\section{The factors contributing to this situation of non-registration of births include:}

1. Lack of awareness among parents about the need for birth registration.

2. Lack of awareness on procedures and locations of birth registration.

3. Low demand for birth certificates.

4. Other problems which includes unavailability of staff, lack of cooperation from the system, lack of knowledge regarding free registration.

5. Registration of birth is being linked to school admission.

\section{OBJECTIVES:}

1. To find the factor influencing birth registration.

2. To study any association between birth registration with literacy, socio economic condition and place of birth.

3. To analyze the trend in registration.

4. To suggest recommendation based on the study.

MATERIALS AND METHODS: This study was conducted in rural as well as urban areas of Kamrup District of Assam during 2009 -2010.The study was approved by the ethical committee of Guwahati Medical College and informed consent was taken. In Kamrup District there were thirty four registering unit of which twenty one are in rural areas and thirteen were in the urban areas. (Source: Office Jt. DHS).

This on calculation came to be sixty percent in Rural Kamrup and fourty percent in Urban Kamrup. It was decided to go for twenty percent of the registering units which was calculated to be seven. It was again divided into four and three according to the percentage of distribution (i.e. $60 \%$ and $40 \%$ ) of the registering units in rural and urban areas respectively.

Thus four registering units in rural area and three units in urban area were selected accordingly. Two villages/wards were selected at random from each registering units. In each village or ward 100 household were visited and data were recorded in predesigned and pretested interview schedule from those household having child between 12-23months of age. A total of 93 households were found but only 86 households were included in the study as the persons present at the household during the time of interview were unable to provide any data.

The data so collected on various aspects of the study were compiled, tabulated and subjected to statistical analysis. Statistical analysis was done manually. Socio economic classification for the present study was done using Prasad Classification. 


\section{ORIGINAL ARTICLE}

TRENDS OF REGISTRATION IN ASSAM AND KAMRUP DISTRICT: The registration in Assam had been experiencing an increasing trend since last few years but a stagnation had been noticed at around 70 $75 \%$ in case of birth registration and around $30-35 \%$ in case of deaths registration. In relation to birth registration it was seen that from $44.2 \%$ in 2001 it reached $74.58 \%$ in 2008.

In regard to death registration the figures were not encouraging, it was seen that there was only marginal increase in level of registration from $22.2 \%$ in 2001 to $31.82 \%$ in 2008. In last two years i.e. in 2007-2008 rather than increasing, a fall in level of death registration had been noticed. (Source: Office of the Director of Health Services, Assam).

In Kamrup District, it was seen that birth registration in 2004 was $49.68 \%$ and it increased to $72.99 \%$ in 2007 , but decreased to $34.58 \%$ in 2008 . Similarly in case of death registration, there was $24.22 \%$ death registration in 2004 and reached $45.29 \%$ in 2007 . Here also registration decreased to $17.3 \%$ in 2008. (Source: Office of the Director of Health Services, Assam).

RESULTS: During the study period 86 births were found in age group 12-23 months. Among these 86 births 53(61.63\%) were registered. In urban areas-27(71.05\%) out of 38 births were registered and in rural areas- $26(54.17 \%)$ births were registered out of 48 births. In case of religion it was noticed that $65.67 \%$ of Hindu births were registered whereas in case of Muslim births it was $47.37 \%$. An association had been found between the level of education and status of registration. But no association had been noted between registration and socioeconomic status or place of delivery.

Those who were registered, most (52.83\%) of them got their certificate after 30 days of registration. Most of them i.e. 14(42.42\%) cited cause of non-registration is being their reluctance to go to the registration unit and get the child's birth registered. Other reasons cited were unaware of the need, distance of registering unit is far, lack of time, noncooperation of staffs, procedure too complicated.

\begin{tabular}{|c|c|c|}
\hline Status of Registration & Number of Respondents & Percentage \\
\hline Registered & 53 & 61.63 \\
\hline Non-registered & 33 & 38.37 \\
\hline Total & 86 & 100 \\
\hline
\end{tabular}

\begin{tabular}{|c|c|c|}
\hline \multirow{2}{*}{$\begin{array}{c}\text { Place of } \\
\text { Residence }\end{array}$} & $\begin{array}{c}\text { Number of } \\
\text { Respondents }\end{array}$ & \begin{tabular}{c} 
Status of Registration \\
\cline { 3 - 3 }
\end{tabular} \\
\cline { 3 - 3 } & & Registered \\
\hline Urban & 38 & $\begin{array}{c}\text { Number } \\
\text { (Percentage) }\end{array}$ \\
\hline Rural & 48 & $27(71.05)$ \\
\hline Total & $\mathbf{8 6}$ & $26(54.17)$ \\
\hline Table 2: Distribution of Births according to Place of residence i.e. \\
Urban and Rural and their Status of Registration \\
\hline
\end{tabular}




\section{ORIGINAL ARTICLE}

\begin{tabular}{|c|c|c|}
\hline \multirow{2}{*}{$\begin{array}{c}\text { Religion of the } \\
\text { Births }\end{array}$} & $\begin{array}{c}\text { Total Number of } \\
\text { Respondents }\end{array}$ & Status of Registration \\
\cline { 3 - 3 } & & Registered \\
\cline { 3 - 3 } & 67 & $\begin{array}{c}\text { Number } \\
\text { (Percentage) }\end{array}$ \\
\hline Hindu & 19 & $44(65.67)$ \\
\hline Muslim & nil & $9(47.37)$ \\
\hline Others & $\mathbf{8 6}$ & nil \\
\hline Total & \multicolumn{2}{|c|}{$\mathbf{5 3 ( 6 1 . 6 3 )}$} \\
\hline \multicolumn{2}{|c|}{ Table 3: Distribution of Births according to Religion and Status of Registration } \\
\hline
\end{tabular}

\begin{tabular}{|c|c|c|}
\hline $\begin{array}{c}\text { Place of } \\
\text { Birth }\end{array}$ & $\begin{array}{c}\text { Number of } \\
\text { Respondents }\end{array}$ & $\begin{array}{c}\text { Number of Registered Births } \\
\text { (Percentage) }\end{array}$ \\
\hline Home & 31 & $18(58.06)$ \\
\hline Health institutions & 55 & $35(63.64)$ \\
\hline Total & $\mathbf{8 6}$ & $\mathbf{5 3 ( 6 1 . 6 3 )}$ \\
\hline Table 4: Distribution of Registered Births According to Place of Birth \\
\hline
\end{tabular}

$\chi^{2}=0.258 \mathrm{df}=1 \mathrm{p}>0.05$

\begin{tabular}{|c|c|c|}
\hline \multirow{2}{*}{$\begin{array}{l}\text { Level of Education } \\
\text { of the Respondents }\end{array}$} & \multirow{2}{*}{$\begin{array}{l}\text { Total number } \\
\text { of Respondents }\end{array}$} & Registered $(n=53)$ \\
\hline & & $\begin{array}{c}\text { Number } \\
\text { (Percentage) }\end{array}$ \\
\hline Illiterate & 11 & $4(36.36)$ \\
\hline Just Literate & 22 & $12(54.5)$ \\
\hline Primary & 24 & $13(54.17)$ \\
\hline Middle school & 10 & $7(70)$ \\
\hline HSLC Passed & 9 & $8(88.89)$ \\
\hline Secondary & 8 & $7(87.5)$ \\
\hline Graduate & 2 & $2(100)$ \\
\hline Total & 86 & $53(61.63)$ \\
\hline \multicolumn{3}{|c|}{$\begin{array}{c}\text { Table 5: Distribution Showing Status of Registration of Births } \\
\text { According to Level of Education of the Respondents }\end{array}$} \\
\hline
\end{tabular}

$\chi^{2}=9.52 \mathrm{df}=4 \mathrm{p}<0.05$

\begin{tabular}{|c|c|c|}
\hline \multirow{2}{*}{$\begin{array}{l}\text { Socio Economic Status } \\
\text { of the Respondents }\end{array}$} & \multirow{2}{*}{$\begin{array}{c}\text { Number of } \\
\text { Respondents }\end{array}$} & Registered \\
\hline & & Number (Percentage) \\
\hline Class-I & 4 & $4(100)$ \\
\hline Class-II & 19 & $14(73.68)$ \\
\hline Class-III & 29 & $16(55.17)$ \\
\hline Class-IV & 21 & $12(57.14)$ \\
\hline Class-V & 13 & $7(53.84)$ \\
\hline Total & 86 & $53(61.63)$ \\
\hline \multicolumn{3}{|c|}{$\begin{array}{r}\text { Table 6: Distribution Showing Status of Registration of Births } \\
\text { According to Socio Economic Status of the Respondents }\end{array}$} \\
\hline
\end{tabular}

$\chi^{2}=2.68 \mathrm{df}=3 \mathrm{p}>0.05$ 


\section{ORIGINAL ARTICLE}

\begin{tabular}{|c|c|c|}
\hline $\begin{array}{c}\text { Place of } \\
\text { Birth }\end{array}$ & $\begin{array}{c}\text { Number of } \\
\text { Respondents }\end{array}$ & $\begin{array}{c}\text { Number of } \\
\text { Registered } \\
\text { Births(Percentage) }\end{array}$ \\
\hline Home & 31 & $18(58.06)$ \\
\hline $\begin{array}{c}\text { Health } \\
\text { institutions }\end{array}$ & 55 & $35(63.64)$ \\
\hline Total & 86 & $53(61.63)$ \\
\hline \multicolumn{2}{|c|}{ Table 7: Distribution of Registered Births } \\
According to Place of Birth
\end{tabular}

$\chi^{2}=0.258 \mathrm{df}=1 \mathrm{p}>0.05$

\begin{tabular}{|c|c|c|}
\hline Cause of Non-Registration & Number of Respondents & Percentage \\
\hline Lack of knowledge & 12 & 36.36 \\
\hline Reluctant & 14 & 42.42 \\
\hline Others & 7 & 21.22 \\
\hline Total & 33 & 100 \\
\hline \multicolumn{2}{|c|}{ Table 8: Distribution of Non-Registered Births (n=33) } \\
According to the Causes of Non-Registration
\end{tabular}

Note: Others include unaware of the need, distance of registering unit is far, lack of time, noncooperation of staffs, procedure too complicated.

SUMMARY: Out of 86 children in age group 12-23 months, 53(61.63\%) were registered and 33 (38.37\%) were non-registered. McCaw-Binns AM et.al. (1996) found in their study that $94 \%$ of live births were registered by one year of age in Jamaica.(3) In the study conducted by Adílson Lopes Cardoso and et. al. at Brazil (2002) it was seen that the rate of unregistered births was $8.6 \% .{ }^{(4)}$

According to UNICEF, India (2005) each year about $42 \%$ of births go unregistered, which is about 10 million births. In NFHS-III (2005-06) it was seen that only $27 \%$ under the age of 5 years had a birth certificate. In a similar study by Megha Gupta they found that $44.2 \%$ of births were registered in their study.(5) It had been seen that $71.05 \%$ of children in urban area had their birth registered whereas only $54.17 \%$ of children in rural area had their birth registration done by their guardians. Similarly in Vanuatu (2005, UNICEF) coverage was good in urban areas but low in rural areas, giving an overall coverage of birth registration was only around 30 per cent.

According to UNICEF, India (2005) birth registration level in the rural areas was lower when compared to the urban areas which was similar to the present study. In Chhattisgarh (2005) it was found that villages near urban areas had $90 \%$ registration whereas remote village inhabited by Tribal people mostly had 10\% registration of births, this study was conducted by State Health Resource Centre.(6) It was seen that majority of respondents in socio economic class I (100\%) and socio economic class II (73.68\%) had registered the births whereas least in social class IV (53.84\%). The difference had been found insignificant. Similarly Adílson Lopes Cardoso and et al. at Brazil (2002) found no association between socio economic status and registration of birth(2) It was seen from that the majority of births (63.64\%) which were registered were from those (55) that occurred in hospital or any other institution. 


\section{ORIGINAL ARTICLE}

In case of births in home only 18(58.06\%) out of 31 were registered. The difference was found statistically insignificant. In the study by SHRC, Chhattisgarh (2005) they found most of the deliveries were home deliveries but in the present study it was seen that most of the births took place in health institution.(6)

ACKNOWLEDGEMENT: I am thankful to retired Prof. Dr. Sajida Ahmed for her expert guidance and Prof. Dr. A. C. Baishya, Head of the Department, Community Medicine for his continuous encouragement, guidance and cooperation. I also thank the respondents who have extended their cooperation during the period of study

\section{RECOMMENDATIONS:}

1. Birth registration should be made free of charge even in case of delayed registration.

2. There should not be any penalty for non-registered.

3. Ensuring adequate registration offices and trained personnel.

4. Birth registration activity and other governmental activities including immunization and school enrolment should be mainstreamed.

5. To improve access to the registering units by decentralizing births and deaths registration units to village level making PRI members responsible for each and every births and deaths.

6. The whole system should be computerized and made online accessible so that births and deaths can be registered without any hassle for those who can access internet.

\section{REFERENCES:}

1. Birth Registration - Right from the Start- a UNICEF publication. Innocenti Digest No .9 - March 2002.

2. National Family Health Survey-3, 2006.

3. McCaw-Binns AM, Fox K, Foster-Williams KE, Ashley DE, Irons B. Registration of births, stillbirths and infant deaths in Jamaica International Journal of Epidemiology.1996 Aug; 25(4):807-13.

4. Adílson Lopes Cardoso, Maria Idalina Marques Fernandes, Antônio Augusto, Moura da Silva, Vânia Maria de Farias Aragão, Raimundo Antonio da Silva; Under-registration of births in the municipality of Centro Novo do Maranhão, 2002 Revista Brasileira de Epidemiologia Vol. 6, № 3, $2003: 237-24$.

5. Megha Gupta, Harsh Maharajand P. Lal awareness about birth registration in a resettlement colony of Delhi, Indian journal of community medicine downloaded on $8^{\text {th }}$ October 2009.

6. Study of Birth Registration in Chhattisgarh: AN SHRC Study; Submitted: September 15th 2006. 


\section{ORIGINAL ARTICLE}

\section{AUTHORS:}

1. Papiya Das

\section{PARTICULARS OF CONTRIBUTORS:}

1. Assistant Professor, Department of Community Medicine, Silchar Medical College.

FINANCIAL OR OTHER

COMPETING INTERESTS: None
NAME ADDRESS EMAIL ID OF THE CORRESPONDING AUTHOR:

Dr. Papiya Das,

C/o. Pramatha Das, House No. 76, Das Colony, Rangirkhari,

Silchar-5, Cachar-788005, Assam.

E-mail: p_d802002@yahoo.co.in

Date of Submission: 06/10/2015.

Date of Peer Review: 07/10/2015.

Date of Acceptance: 16/10/2015.

Date of Publishing: 23/10/2015. 